\title{
Itinerario
}

http://journals.cambridge.org/lTI

Additional services for Itinerario:

Email alerts: Click here

Subscriptions: $\underline{\text { Click here }}$

Commercial reprints: $\underline{\text { Click here }}$

Terms of use : $\underline{\text { Click here }}$

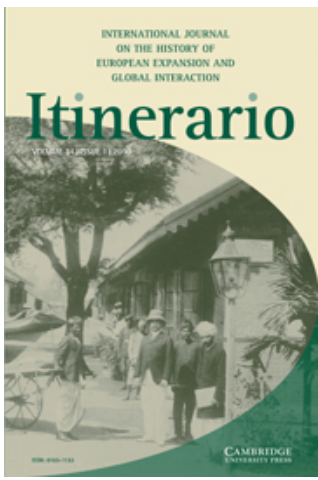

\section{Liam Matthew Brockey, ed., Portuguese Colonial Cities in the Early Modern World. Farnham, UK: Ashgate, 2008. 282 pp. ISBN: 9780754663133 (hbk.). I $\$ 54.00$.}

Katrina Gulliver

Itinerario / Volume 34 / Special Issue 01 / March 2010, pp 145 - 147

DOI: 10.1017/S0165115310000252, Published online: 01 April 2010

Link to this article: http://journals.cambridge.org/abstract S0165115310000252

How to cite this article:

Katrina Gulliver (2010). Review of Christopher L. Tomlins 'Freedom Bound: Law, Labor, and Civic Identity in Colonizing America, 1580-1865' Itinerario, 34, pp 145-147 doi:10.1017/S0165115310000252

Request Permissions : Click here 


\section{EUROPE AND THE WIDER WORLD}

Liam Matthew Brockey, ed., Portuguese Colonial Cities in the Early Modern World. Farnham, UK: Ashgate, 2008. 282 pp. ISBN: 9780754663133 (hbk.). \$54.00.

As the title suggests, this book offers a selection of essays on different cities in the Portuguese Empire. The contributions developed from papers given at a conference at Princeton in 2004. The links between articles, and the specific references drawn by the authors to other works in the volume, shows how well-chosen and complementary they tend to be. The stated aims of this volume are to answer the question of the relationship between city and empire (9). Brockey asserts that the collection is responding to Charles Boxer's questions of the colonial city in the Portuguese empire, and it also complements (and acknowledges) recent work on the field including that of Diogo Ramada Curto and Francisco Bethencourt.

The first chapter, "In the Shadow of Empire: Portuguese Jewish Communities in the Sixteenth Century", José Alberto Rodrigues da Silva Tavim looks at the Portuguese Jewish diaspora. Sadly, the title term of "shadow" is correct; much of these communities' histories 
is speculative. Nonetheless, their presence as a minority group throughout the Portuguese empire is an important thread in the development of colonial societies.

Charlotte de Castelnau-L'Estoile writes well on the uses of the city for procession and display. Her chapter on Salvador de Bahia is one of the most instructive in the book, in terms of how to approach colonial urban history. By taking key events of Jesuit history in relation to the Indians, a layered narrative of the city emerges.

The essay on Nagasaki by J. S.A. Elisonas is-as Brockey notes in his introduction-the "joker in the pack". This Nagasaki piece, while offering a fascinating and detailed study of one community's relationship with Christianity, has little to add to the conversation about the Portuguese. It would perhaps have been better placed in a volume about Christianity in Japan. I suspect in this volume it is unlikely to reach the readership it deserves.

Malyn Newitt offers a study of decline in his chapter on Mozambique Island. This demonstrates the combination of luck and an evolving economy that resulted in this port falling into decay while other Asian colonial ports such as Singapore and Mumbai flourished. In the mid-sixteenth century, trade in gold and ivory brought success to this fortress city. The population stagnated, there was no will to invest in infrastructure, and in a meta-gesture of resignation, the city was turned into a penal colony.

Glenn J. Ames writes on the "Province of the North" and its cities. In this case the religiosos overplayed their hand, driving traders to Bombay (then controlled by the English East India Company), where they could enjoy freedom of religion. This essay, offering an overview of a region rather than a study of a particular city, helps to contextualise some of the others. Isabel dos Guimarães Sá's piece on the Misericórdias of Macau offers a detailed examination of the fissures of race and religion. These lay confraternities flourished throughout Portugal and her Empire. As well as illustrating the strata of urban society, this piece demonstrates the ways in which histories of race can be challenged. For the Chinese of Macau, conversion was often a path to ostracism rather than inclusion, and their sense of betrayal by the Misericórdias is detailed here.

These confraternities could serve a particular role in colonial economies, performing proto-banking functions. They amassed capital and invested or lent to finance planting and trade. In addition, they became a key element of the social establishment, with membership a part of acceptance into that hierarchy. Their selective benevolence also helped them to shape the social order, for instance with the provision of dowries for deserving poor girls to marry.

Stuart B. Schwartz focuses on the nature of power in the colonial sphere, in his chapter "The King's Processions: Municipal and Royal Authority and the Hierarchies of Power in Colonial Salvador". He points out the contradictory purpose of such pageantry, both reaffirming loyalty to the crown, but also asserting local power. The importance of these planned rituals in creating a shared historical memory (and sense of identity) was perhaps more important for those living in colonial locations than for those in Lisbon. Within the ceremonies, parades offered the opportunity to assert local hierarchies by participants' roles in the procession.

Diogo Ramada Curto's "Notes on a Project for the City of Goa" looks at Captain Diogo de Pinho Teixeira's 1728 plan for reform. This broad plan encompassed almost all aspects of urban life and so serves to illustrate the practices of the city through the reformer's concerns. He prescribes strict religious observance, and attempts to limit the abuse of slaves. The plan attempted to reorder the urban space to affirm white, Christian, male authority. Prostitutes would be relegated to certain areas, and women in general subject to various restrictions on their public conduct. The reforming impulse, demonstrating the colonial sphere as a zone of experimentation, was stronger in a city where so many of the residents appeared (by language, race, and religion) to be outside Portuguese control.

The chapter on representations of Empire, by Kirsten Schultz, looks at the Empire as reflected in a colonial site. She points to a recurring colonial anxiety: how residents of a 
colony could demonstrate (or gain) the same degree of prestige in the Empire as residents of Portugal. This particular anxiety has also been addressed by scholars of the British Empire, and it is interesting to see the early arrival of such preoccupations in Brazil. For a resident of Brazil, the presence of slaves; free people of African descent; and indigenes, made the emphasising of one's Portugueseness more important. But the spectacles of loyalty to the crown also attempted to include these non-white subjects of the Empire, asserting their fealty to the king.

Catarina Madeira Santos in the final chapter addresses Luanda, which was built by the Portuguese, and was the oldest of their cities on the West African coast. She describes the syncretism of European and African symbolism in the urban space. In their ongoing attempts at legitimisation, the longstanding Portuguese residents asserted their time of residence, loyalty, and their families' contributions to maintaining a Portuguese empire in Africa. However, their links (also through their ancestors) to the slave trade were "forgotten" or dismissed in this self-created identity. However, the process of creolisation in the city created a new identity, linked to geography as well as ethnicity, and linguistic boundaries became blurred.

This volume offers useful contributions for those interested both in the history of the Portuguese empire, and the nature of the "colonial city". The challenges and value of studying cities in a colonial hierarchy are well elaborated in the introduction. Brockey also discusses viewing cities horizontally rather than vertically: in that sense we also need to look at the cities of other Empires at the same time. Work on the Portuguese empire can only be enhanced by studies of Spanish colonial cities, especially during the period of Enlightened Reform. Nonetheless, this book opens the door to further studies in the area, and for this Professor Brockey is to be thanked. He also translated several of the chapters, and shows a fluid style, which is to be highly commended (the translation of academic works presents a particular challenge as many readers will know). In fact, Brockey's thoughtful introduction, which includes a lengthy discursion on Malacca, made me wish he had written a full chapter on that city. 